\title{
Analysing Civil Society in Weak States
}

To explore how civil society constitutes itself in weak states and how the state and other factors, such as a country's historical legacy, its political system, its ethnic composition, its majority religion, or its level of economic growth, influence the development of national civil societies, this study takes the empirical, analytical literature on civil society as a starting point (e.g. Alexander 1998; Guan 2004; Lauth 2003; Lewis 2001; Wischermann 2005). Notably, this literature suggests that the concept of civil society must be systematically contextualized. A relational understanding that consequently relates civil society to the context of action in which it operates is a fruitful approach to this endeavour (Lorch 2006). Building on the works of Alexander (1998, pp. 7f.), Gosewinkel (2003), Gosewinkel and Rucht (2004), Gosewinkel et al. (2004) and Croissant et al. (2000, pp. 1lff.), such a relational approach assumes that in real, existing civil societies, normative characteristics, such as "civility", the generation of social capital and the performance of certain democratic functions, can exist only in degrees. Concurrently, the relational approach likewise supposes that real, existing civil societies will also always display certain dark sides, such as clientelism and organizational hierarchies, and that the relationship between the democratic features and dark sides within such real, existing civil societies depends on the scope of action available to civil society actors.

The original version of this chapter was revised. An erratum to this chapter can be found at https://doi.org/10.1057/978-1-137-55462-8_7

(C) The Author(s) 2017

J. Lorch, Civil Society and Mirror Images of Weak States, Governance and Limited Statehood, https://doi.org/10.1057/978-1-137-55462-8_2 
When analysing national civil societies in particular countries, the relational approach selects the civil society groups to be studied on the basis of the broad, predominantly empirical definition of the CCS-LSE (2006), which encompasses a large variety of associations that can differ tremendously in terms of their organizational characteristics. It then proceeds to describe how these civil society groups constitute themselves within, and because of, their specific empirical context, and to what extent they are characterized by democratic features and dark sides, respectively. More specifically, it can be assumed that real, existing civil society groups will always display a certain degree of autonomy from the state, political society and the market and can, therefore, be characterized by a certain extent of self-organization and self-regulation. As far as their internal organizational structures are concerned, civil society groups are likely to show a certain commitment towards horizontal forms of decision-making and practise some measure of accountability and transparency. Similarly, they can, to a certain degree, be assumed to be inclusive and pluralistic in nature and to bridge social cleavages. Accordingly, real, existing civil societies, in this sense, can be expected to be characterized by a certain degree of "civility" and, to a certain extent, to perform democratic functions, such as watchdog and representative functions or the generation of social capital. Similarly, they may, to a certain degree, act as democratic intermediaries, conveying the needs and interests of marginalized social groups to the state (e.g. Anheier et al. 2000; Anheier et al. 2003, esp. p. 137; Cohen and Arato 1992; Diamond 1999, pp. 228-250; Putnam 1993; Priller and Zimmer 2003). ${ }^{1}$ At the same time, however, the autonomy of real, existing civil society groups is always bound to be limited and, depending on the context in which they operate, the internal structures of civil society organizations may also display unrepresentative, exclusive and hierarchical features. Moreover, in real-world settings, civil society groups can be tainted with varying degrees of informality, clientelism, or even violence. The social capital they generate may also be particularistic, at least to a certain extent. Consequently, it can be assumed that a vibrant civil society is not always good for democracy (e.g. Lauth 2003; Monga 2009; Ottaway 2004; Roniger 1998; Verkoren and van Leeuwen 2014).

Moreover, the empirical, analytical literature on civil society also suggests that both the relationship between the democratic features and the dark sides of real, existing civil societies and the relationship between the internal organizational structures and the democratic potential of civil society groups are complex in nature. For example, Alexander (1998, pp. 7f) has argued that where there is a high degree of "interpenetration" between the sphere 
of civil society and the state (or other social spheres, such the market), the resulting lack of autonomy of civil society can lead to the emergence of "non-civil" forms of behaviour within the sphere of civil society. Similarly, several empirically oriented studies show that civil society groups whose internal organizational structures are hierarchical and do not allow for active involvement of their members in decision-making often fail to perform a representative function and are frequently unable to contribute to popular participation (e.g. Edwards and Hulme 1996a, b; Tandon 1996). Under certain conditions, however, so-called dark sides, such as a lack of internally democratic structures, may also enable civil society actors to perform certain democratic functions. Rueschemeyer's (1998, pp. 13f.; 16) reflections on the relationship between internal organization and organizational effectiveness suggest, for instance, that especially where the social and political system is exclusive, hierarchically structured groups may sometimes be more effective in the struggle for a widening of avenues for popular representation than internally democratic ones. Similarly, German transition theory finds that the readiness of civil society actors to militantly oppose existing power structures can play an important role in making a democratic transition succeed. Once democracy is established, however, such militant modes of behaviour may weaken democratic institutions and prevent civil society from serving an intermediary function between citizens and the state (Croissant 2000, pp. 354-62.; see also Croissant et al. 2000).

\subsection{The State as the Context of Action for Civil SOCIETY}

The relational approach suggests that the relationship between the democratic potential and the dark sides of civil society is contextually contingent. But what are the contextual conditions that can be expected to be most relevant in shaping national civil societies? As noted earlier, the existing literature has identified various factors that may influence national civil societies, including, in particular, a country's historical legacy, its political system, its ethnic composition and majority religion, its level of economic growth and the strength or weakness of the state. A quick comparison of Bangladesh and the Philippines, following a most dissimilar cases design, suggests, however, that the relative strength or weakness of the state constitutes the most important condition that influences the ability of civil society to emerge, exert political influence and contribute to democratization. This preliminary empirical finding is supported by several works that touch upon the relationship between civil society and 
the state (e.g. Götze 2004; Gosewinkel 2003, pp. 1, 9ff; Gosewinkel et al. 2004, p. 14f., 18-21; Englehardt 2011; Evans et al. 1985; Kaviraj 2001, pp. 366ff.; Knöbl 2006; Reichardt 2004, pp. 65-68; Rueschemeyer 1998, esp. pp. 18f.; Rueschemeyer et al. 1998a, pp. 4ff.; Stepan 1985; Weiss and Hobson 1995; pp. 1-10, 238-252). Weiss and Hobson, for instance, stress the causal primacy of the state in shaping the development of civil society (Weiss and Hobson 1995, pp. 1-10, 238-252), and Kaviraj (2001, pp. 366ff.) points to the pre-eminent role played by the (post-)colonial state in structuring civil societies in developing countries. Similarly, Gosewinkel (2003, pp. 9ff.) has noted that, depending on its specific character, the state can constitute either an enabling condition for or an impediment to the emergence and existence of civil society.

But what kind of state produces what kind of civil society? Englehardt (2011, p. 337) argues that common theories of civil society, which build on liberal democratic theory and were influenced by the historical experience of the democratic transformations in Eastern Europe, tend to view "civil society as spontaneously self-organized harmony". Civil society, in this sense, is perceived as a bulwark against despotic state power and is supposed to flourish best when the state interferes least. Drawing on theoretical considerations, the case of Somalia and available cross-national data, Englehardt (2011) refutes these assumptions. Instead, he proposes an alternative, Kantian view of civil society according to which a harmonious civil society can emerge only after the state has reduced violence and established centralized control over predatory groups. The development of a strong and "civil" civil society, in this sense, requires a strong state. Ultimately, Englehardt argues, this finding is also confirmed by the democratic transformations in Eastern Europe, where strong and democratically oriented civil societies emerged in authoritarian states that were, however, strong and centralized (ibid, pp. 356f. $)^{2}$. This corresponds with the neo-statist approach, advanced by Weiss and Hobson (1995, pp. 1-10, 238-252), which assumes that strong states and strong civil societies constitute two sides of the same coin. The conclusion that a strong and democratic civil society requires a strong state is also shared by other authors who have focused on the relationship between civil society and the strength, or weakness, of the state. For instance, Götze's (2004, pp. 201ff.) work on the Red Cross in Bosnia-Herzegovina and Albania also shows the importance of the state's monopoly on the use of force and the existence of a reliable legal framework for the emergence of a civil society that is strong and democratic. Götze argues that civil society in this sense is legally enabled, framed and protected by the state, and that by holding a monopoly on 
force and by establishing binding rules for social behaviour a strong state constitutes an important precondition for an autonomous and non-violent civil society to emerge (see also Gosewinkel et al. 2004, pp. 14f.; 18-21; Knöbl 2006; Reichardt 2004, pp. 65-68).

However, Götze (2004, pp. 201ff.) also states that to conclude that civil society can only exist in strong states would be misleading, because in many developing countries voluntary associations flourish precisely because the state is weak. This view is shared by other authors who focus on the development of civil society in weak states and in the developing world more generally (e.g. Croissant et al. 2000; Lorch 2006, 2008; Ottaway 2004, p. 125; Shah 2008). The research on governance in areas of limited statehood also supports this view, showing that in contexts where central state institutions are weak, civil society actors, such as NGOs, often take over functions normally ascribed to the state (e.g. Risse 2012, pp. $5 \mathrm{ff}$.).

This apparent paradox is unravelled by Ottaway (2004) who shows that, while in many weak states civil society groups exist in abundance, they often constitute themselves differently from what is assumed by normative civil society theory. Specifically, Ottaway's analysis suggests that civil society groups operating in weak states may often lack autonomy from powerful social forces and frequently engage in rather uncivil forms of behaviour. This finding corresponds with other studies on civil society in weak states, which likewise suggest that so-called dark sides characterize civil society especially in contexts where the state is weak (e.g. Englehardt 2011; Götze 2004; Lorch 2006, 2008; Shah 2008).

But how exactly does state weakness lead to the emergence of dark sides in civil society? The few existing theoretical investigations into this issue often revolve around the state's monopoly on the use of force (e.g. Englehardt 2011; Götze 2004; Knöbl 2006; Reichardt 2004). More precisely, it has been argued that the centralization of the means of violence in the hands of the state leads to pacification, creates social order and generates predictability, thereby enabling the development of voluntary associational activities (Englehardt 2011, pp. 338ff.; see also Reichardt 2004, pp. 65-68). Similarly, it has been noted that the state's monopoly on force, compulsory education, conscription and taxation have a disciplinary effect on society, because they lead to social affect control and promote the sublimation of aggressions (Götze 2004, p. 201; Knöbl 2006, pp. 4ff.; Reichardt 2004, pp. 62-68). In this sense, the varying degrees of "civility" of different national civil societies can be seen to depend on the extent to which the states in which they operate manage to uphold a monopoly on force (Gosewinkel et al. 2004, pp. 18-21.; Knöbl 2006, pp. 1-7; Leonhard 
2004; Reichardt 2004, pp. 65-68.). On the whole, however, existing studies have not been able to sufficiently operationalize these theoretical findings in order to explain how state weakness may generate the various different types of dark sides that real, existing civil societies have been found to display.

To solve this problem, the present study disaggregates the phenomenon of state weakness and also examines the social and political conditions in which weak state institutions are embedded. Specifically, the literatures on governance in areas of limited statehood and on weak states show that the prevalence of an environment in which non-state actors perform functions normally ascribed to the state (e.g. Beisheim et al. 2014; Risse 2015), the existence of powerful social forces that compete with the central state for social control (see especially Migdal 1988), the widespread use of patronage and corruption by state elites and powerful non-state actors (e.g. Eriksen 2005), the prevalence of a context of violence and insecurity (e.g. Biró 2007; Schneckener 2006) and external influences in the form of international aid (e.g. Carothers and Ottaway 2000) are highly interrelated with the weakness of central state authorities. Interestingly, the few existing studies on civil society in weak states (e.g. Englehardt 2011; Götze 2003; Lorch 2006, 2008; Shah 2008; Verkoren and van Leeuwen 2014) and the broader empirical analytical literature on civil society (e.g. Alexander 1998; Croissant et al. 2000; Lauth 2003; Roniger 1998) have also identified these conditions as having an important impact on national civil societies. Drawing on this, the book investigates whether and how these conditions influence civil society in weak states. In order to specify these further, the study also draws on previous scholarship on state-society relations in "weak" or "soft" states (e.g. Migdal 1988; Myrdal 1968), as well as on the literatures on patronage (e.g. Landé 1977; Lemarchand 1981; Scott and Kerkvliet 1977), on violent non-state actors (e.g. Biró 2007; Mair 2002; Schneckener 2009) and on foreign-funded NGOs (e.g. Banks et al. 2015; Banks and Hulme 2012; Edwards and Hulme 1996a, b).

Building on analytical categories that can be found in both the literature on civil society, and in the literatures on governance in areas of limited statehood and on weak states, the theoretical analytical framework, which guides the empirical analysis of this book, constitutes a "focused theory frame" following Rueschemeyer (2009, pp. 12-17). As such, the framework cuts across the research on civil society, on governance in areas of limited statehood and on weak states, and structures the book's theoretical 
and empirical investigation into the relationship between civil society and state weakness. However, while "theory frames" have a sharp focus and constitute highly effective "analytical tools", they do not constitute comprehensive theories (ibid). Consequently, the book's theoretical analytical framework also falls short of determining the multiple connections and interrelations that might exist between the analytical categories and tentative causal patterns it identifies. Moreover, to ensure that its findings can be generalized on a higher theoretical level, the present study must combine the application of its "focused theory frame" with the Comparative Method in the form of the most dissimilar cases design and with structured, focused comparison.

The following sub-chapters develop the five analytical categories of influences that shape civil society in weak states: first, the existence of an environment where non-state actors perform functions normally ascribed the state (Sub-chap. 2.2); second, the lack of state autonomy and the prevalence of a social conflict between different alternative power centres inside and outside the state apparatus (Sub-chap. 2.3); third, the existence of a context of patronage and corruption (Sub-chap. 2.4); fourth, the prevalence of an environment of violence and insecurity (Sub-chap. 2.5 ); and, fifth, external influences in the form of international aid, which are conceptualized as an important intervening variable that can have an impact on both civil society and the state (Sub-chap. 2.6). Specifically, the following theoretical sections will focus on the influence that these contextual conditions can have on the ability of national civil societies to emerge, exert political influence and contribute to democratization. Throughout the book, the influence that other possible independent variables, such as the country's historical legacy, its political system, its ethnic composition, its majority religion or its level of economic growth, may have on national civil societies is tested empirically through comparative methods.

As noted, the empirically oriented literature on civil society suggests that real, existing civil societies generally mirror the contexts in which they operate (e.g. Croissant 2000, esp. p. 360; Howell 1999; Lauth 2003, pp. 40ff.). Taking this as a starting point, the following theoretical and empirical analysis builds on the guiding assumption that national civil societies in weak states mirror the deficits of their respective states across the abovementioned categories of state weakness. 


\subsection{Civil Society in a Context Where Non-State Actors Perform Functions Normally Ascribed TO THE STATE}

Existing studies on civil society in weak states have found that in such contexts civil society actors often take over functions normally ascribed to the state, such as the provision of welfare services (e.g. Götze 2004, pp. $201 \mathrm{ff}$;; Lorch 2006, 2008; Ottaway 2004; Rombouts 2006, p. 32; Shah 2008, p. 39; Verkoren and van Leeuwen 2014, p. 469; Weijer and Kilnes 2012, pp. 12ff.; Zaidi 2006, p. 3557). Similarly, the literature on governance in areas of limited statehood shows that, where central state institutions are weak, essential collective goods are often provided by different types of non-state actors, including private businesses, public-private partnerships or NGOs and other civil society groups (e.g. Beisheim et al. 2014, pp. 3ff.; Risse 2012, pp. 5ff.). This finding is supported by scholarship on weak states, which argues that if the state fails to perform its functions with regard to the provision of social services, security or other political goods, other actors can move into the gaps that exist (e.g. Milliken and Krause 2003, p. 15; Rotberg 2004, pp. 6ff.; Schneckener 2006). Against this backdrop, this sub-chapter explores the relationship between the existence of an environment in which non-state actors perform functions normally associated with the state and the ability of national civil societies to constitute themselves.

The existing literature on civil society in weak states clearly suggests that the inability or unwillingness of the state to perform certain functions and the subsequent self-help efforts of local communities to provide makeshift solutions to the resulting problems can be highly conducive to the emergence of civil society (e.g. Götze 2004, pp. 201ff.; Lorch 2006, 2008; Ottaway 2004; Shah 2008, p. 39; Zaidi 2006, p. 3557). But what are the specific functions that can be assumed by civil society actors, and what are the specific sectors in which civil society is most likely to emerge in contexts of state weakness?

Studies that rely on a functional understanding of state weakness largely fall short of illuminating the social and political conditions that influence national civil societies in weak states. However, they delineate and describe the functions that are normally attributed to modern states and can thus be used to identify the sectors in which civil society actors may become active in contexts of state weakness. Specifically, many of these studies identify three core functions that are normally associated with the state: first, the 
delivery of social services; second, democratic institution-building; and, third, the provision of security (e.g. Doornbos 2003; Milliken and Krause 2003; Rotberg 2002, 2004; Schneckener 2006). To what extent are civil society actors capable of performing these functions if the state is unable or unwilling to do so?

There is a relatively broad consensus in the existing literature on civil society in weak states that civil society groups can provide makeshift solutions in the field of social service provision. Civil society actors, such as community-based associations, NGOs or religious groups, can cater to fundamental welfare needs not met by the state, such as the provision of food, healthcare or education (Götze 2004, pp. 201ff.; Lorch 2006, 2008; Ottaway 2004; Shah 2008, p. 39; Verkoren and van Leeuwen 2014, p. 468; Zaidi 2006, p. 3557). As Ottaway points out, if civil society organizations have access to sufficient resources, they can develop into professional agencies that may deliver welfare services more effectively than weak state bureaucracies. As such, in many weak states, civil society groups constitute the most important providers of welfare services (Ottaway 2004, p. 129). Notably, studies on civil society under authoritarian rule suggest that this can be the case even if the political system is highly authoritarian (e.g. Croissant et al. 2000, pp. 28f.; Lorch 2006, 2008).

But how do civil society groups active in the welfare sector relate to the institutions and the bureaucratic elites of the weak state? In strong states, civil society-based welfare organizations often form part of mixed-welfare systems, complementing social service delivery by the state. Moreover, where central state institutions are strong, the delivery of social services by civil society is usually coordinated, monitored and regulated by the state (e.g. Evers and Laville 2004; Lamping et al. 2002; Lewis 2004). By contrast, in contexts where the bureaucratic institutions of the state are weak, the delivery of social services may simply be left to NGOs and other civil society groups without any kind of coordination or supervision (Ottaway 2004, p. 131; see also Edwards and Hulme 1996a, p. 5). Sometimes, mixed-welfare systems and contracting-out arrangements may formally be in place in weak states as well. But if regulatory state institutions lack capacity and the political environment is characterized by patronage and corruption, such systems of complementary service provision may become severely distorted (e.g. Smith 2004, esp. pp. 166f.). However, the question of how this may influence civil society groups active in the welfare sector has not yet been sufficiently explored. 
The existing research on civil society also shows that the capacity of citizens to participate in voluntary associations is dependent on their socioeconomic and educational backgrounds (e.g. Lamping et al. 2002, p. 20; Reichardt 2004, p. 74). More specifically, where comprehensive welfare provision and broad-based access to education are not in place, civil society groups may often be unrepresentative in nature and exclude citizens belonging to marginalized social strata (e.g. Reichardt 2004, pp. 73f.; see also Rueschemeyer et al. 1998b; p. 281). Ottaway (2004, pp. 128ff.) and Shah $(2008$, p. 35$)$ show that a lack of representativeness and elitist features characterize civil society organizations particularly in contexts where the state is weak. As Ottaway (2004, p. 129) notes, for instance, in weak states, civil society elites frequently make claims on behalf of certain constituencies without being accountable to the latter. Additional research is needed, however, to clarify to what extent such problematic features can be attributed to the weakness of the state and/or the lack of comprehensive social service provision, and what role the level of economic development and international factors - such as foreign donor influences - may play in this regard.

As noted earlier, normative approaches to civil society generally suppose that civil society actors are also capable of contributing to democratic institution-building. Therefore, international donor programmes aimed at the promotion of democracy frequently entail measures to encourage civil society growth (e.g. Carothers and de Gramont 2013, pp. 136ff.; Carothers and Ottaway 2000). Contrary to this view, the more empirically analytical literature on civil society is sceptical about the ability of civil society to promote democracy. Based on the cases of Bangladesh and the Philippines, the questions of whether and to what extent civil society actors in weak states are able to exert political influence and contribute to democratization will be tackled throughout the book, and the answers will be presented in the comparative chapter and in the conclusion. In addition, the empirical chapters will also explore the question of whether civil society can contribute to democratic institution-building by empirically assessing the contributions that civil society actors in Bangladesh and the Philippines have been able (or unable) to make in the field of election monitoring.

Some authors suggest that in weak states civil society actors may, at times, also provide makeshift solutions in the field of security provision (e.g., Ottaway 2004, pp. 126f.; see also Andersen 2006, pp. 15ff.). Ottaway (2004, p. 127) claims, for instance, that in contexts of state weakness "(v)igilante groups ... are a civil society response to insecurity". 
Similarly, Gosewinkel and Reichardt (2004, p. 65f.) suggest that certain violent actors, such as gangs and vigilante groups, are often characterized by organizational features that are suposedly found in civil society as well, such as self-organization and mutual solidarity (see also Reichardt 2004, p. 69). However, the ability to effectively provide physical security ultimately depends on a group's capability to use organized violence, and most definitions of civil society exclude such groups. Accordingly, many authors define vigilante groups not as civil society actors but as non-state armed groups (e.g. Schneckener 2009). Nevertheless, additional research is necessary to explore the extent to which civil society actors in weak states may be able to provide security as well as whether and to what extent they may have to link up with or transform themselves into armed groups for this purpose.

On a more general level, it must be asked whether civil society groups that operate in weak states where the authority of central state institutions is contested by powerful non-state actors (e.g. Migdal 1988) can perform any of the above-mentioned functions independently at all, or whether they have to align themselves with state elites or alternative power players for this purpose. Conversely, investigating whether non-state power players trying to increase their social and political influence in the weak state strive to co-opt civil society groups that deliver social services or other benefits not provided for by the state would also appear to be useful. These questions will be explored in the following sub-chapter.

\subsection{Civil Society in the Context of Power Centre Competition}

Empirical case studies on civil society in weak states show that, in such contexts, civil society groups are often aligned with powerful social forces, such as state elites, semi-authoritarian political parties or insurgent groups (Götze 2004; Lorch 2006, 2008; Shah 2008; South 2007; Verkoren and van Leeuwen 2014; see also Ottaway 2004). At the same time, state capacity approaches to state weakness stress that weak states generally exist in an environment of social conflict and lack autonomy from alternative power players, such as military factions, powerful political parties, local strongmen or warlords (Migdal 1988; see also Biró 2007; Chesterman et al. 2004; Migdal and Schlichte 2005). Against this backdrop, the current sub-chapter seeks to identify tentative theoretical linkages between the limited autonomy of the state, the existence of non-state power players and the limited autonomy of civil society in weak states. 
While strong states are autonomous bureaucratic entities that hold a monopoly on the use of force and are capable of enforcing authoritative decisions and controlling the social sphere, the autonomy and the authority of weak states are contested by powerful social forces, that is alternative power centres (Migdal 1988; see also Biró 2007; Eriksen 2005; von Trotha 2005). Drawing on Migdal (1988), this study uses the term alternative power centre to denote collectives of political and/or social elites both inside and outside the state apparatus, which are capable of circumventing the state's formal rules and have the power to exercise social control over significant parts of the population. ${ }^{3}$ Alternative power centres include collective elites as different as military units, landed dynasties, political parties, insurgent groups and religious organizations (Biró 2007; Eriksen 2005; Migdal 1988; von Trotha 2005). Weak state bureaucracies compete with such alternative power centres for social control in an environment of social conflict (Migdal 1988).

Weak states are fragmented polities and "oligopol(ies)" of authority in which dependent segments of the population are controlled vertically by state elites and alternative power centres (Migdal 1988, esp. pp. 208ff.; see also Ruud 1996, esp. p. 19lf.). As Chesterman et al. (2004, p. 5) note, where a strong and neutral bureaucracy is lacking, even the existence of vibrant political parties, otherwise an important prerequisite for democracy, can enhance political fragmentation, as the former may capture the judiciary and other parts of the state and import inter-group conflict into public institutions. Obviously, there are different degrees to which the autonomy of the state can be curtailed by alternative power centres, and weak states can be linked to alternative power centres in various ways (Biró 2007, pp. 4lff.; Migdal 1988, esp. pp. 206-258; Migdal and Schlichte 2005, p. 19). In some cases, certain bureaucratic entities of the state may be connected to alternative power centres through flexible alliances and negotiated settlements (Migdal 1988, esp. pp. 206-258; see also von Trotha 2005 , pp. 36f.). In others, by contrast, state elites may be able to establish a certain amount of supremacy over alternative power centres by co-opting or even incorporating them into the state apparatus (Migdal 1988, pp. 229ff.). However, alternative power centres, such as elite families, military units, warlords or local strongmen, may also actively seek to capture the state, or parts of it, for the purpose of enhancing their own social and political influence (Biró 2007, pp. 24ff.; Chesterman et al. 2004, pp. 2ff.; Eriksen 2005, pp. 397ff.; Migdal 1988, pp. 238-258). The various types of alliances that can exist between state institutions and alternative power centres may differ considerably in terms of their flexibility and durability. 
How do these patterns and dynamics influence civil society? As noted, conventional approaches generally define civil society as an autonomous social sphere that is characterized by a high degree of self-organization. In contrast to this, the relational approach supposes that the degree of autonomy of real, existing civil societies depends on their context of action and, in particular, the state in which they operate (for a related argument see Gosewinkel 2003, pp. 9ff.; Gosewinkel and Rucht 2004; Gosewinkel et al. 2004, pp. 14f.; 18-21). Similarly, empirical case studies show that in weak states civil society groups are often affiliated with powerful social forces, which can be considered as alternative power centres as defined in this study (Götze 2004; Lorch 2006; Ottaway 2004; Shah 2008; South 2007). For instance, Götze's (2004, esp. p. 208) work on Bosnia-Herzegovina suggests that where the state fails to guard both its own autonomy and the autonomy of the public sphere, civil society becomes vulnerable to cooptation by political elites. Most existing studies on co-opted civil society groups focus on co-optation by elites in authoritarian regimes (e.g. Heng 2004; Lorch 2006; Perinova 2005; Yang 2004). However, several authors also show that, in contexts of state weakness, civil society groups can likewise be aligned to powerful opposition groups, such as opposition parties or even warlords or insurgent movements (Biró 2007, p. 43; Ottaway 2004, p. 130; Shah 2008; South 2007).

The work of Migdal suggests that alternative power centres will enter into alliances with civil society primarily for the purpose of enhancing their social control (Migdal 1988, esp. pp. 24-33). Some empirically oriented studies confirm and provide further insight into this pattern. Biró (2007, esp. pp. 37-43) shows, for instance, that both in Africa and Afghanistan, warlords seeking to stabilize their rule have often had to move beyond coercion and provide social services to local constituencies. However, as their primary character as entrepreneurs of violence has often prevented them from directly engaging in service delivery, many of these warlords have established linkages with civil society groups, such as "local solidarity networks" or foreign-funded NGOs. Moreover, several warlords have even transformed some of their armed factions into welfare-oriented groups. Similarly, armed ethnic groups in Burma have often sought to support the development of the regions they control by opening up spaces for civil society groups, such as NGOs (Lorch 2006, pp. 24ff.; South 2007). This indicates that alternative power centres may deliberately seek to make use of the ability of civil society groups to provide social services in order to enhance their potential for social control. Further research is needed, however, in order to explore this assumption further. 
Moreover, Linz's (2000, pp. 175ff.) elaborations on mobilizational authoritarian regimes, Midgdal's (1988, pp. 232ff.) work on the Institutional Revolutionary Party (PRI, Partido Revolucionario Institucional) of Mexico and Biró's (2007) research on violent non-state actors suggest that socialist parties, liberation movements or "reform insurgencies" (Biró 2007) in particular may also establish or co-opt loyal civil society groups for the purpose of spreading their political beliefs and enhancing their ideological control. Based on the case of Nepal, Shah (2008, p. 46) further argues that in weak states, different types of political parties may use civil society as a "mobilization strategy" to build popular support for regime change. Additional, comparative insights are needed, however, to gain a more thorough understanding of why alternative power centres may link up with civil society groups and whether specific types of alternative power centres are more likely to engage with civil society than others.

Similarly, the questions of why civil society actors link up with alternative power centres and how such alliances impact on these actors' ability to exert political influence have also remained largely unexplored so far. Studies on civil society in authoritarian contexts have argued that civil society actors may deliberately allow themselves to become co-opted by political elites in order to promote their own interests (e.g. Yang 2004, pp. 13f.; Perinova 2005, pp. 6ff., 28). Similarly, Shah (2008, esp. pp. ix, 25ff., 46f.) shows that in the weak state of Nepal, civil society actors forged an alliance with the armed Maoist party to overthrow the monarchy. Moreover, those civil society groups that played an important role during the transition were also able to exercise considerable influence on the post-transition government. Similarly, in Pakistan, various secular NGOs welcomed the military coup of Pervez Musharraf, because they perceived it as a remedy against growing Islamization. After the coup, several NGO leaders acted as service contractors, advisers or even cabinet members of the military government, which provided them with substantial political influence (Zaidi 2006). Comparative findings are needed, however, to investigate these issues in depth.

How do alliances between civil society groups and alternative power centres impact the structure of civil society? Existing studies on civil society in weak states suggest that national civil societies that are characterized by power centre alignments will mirror the structure of the power centre competition which prevails in the respective weak state (Götze 2004; Rombouts 2006, p. 34ff.; Weijer and Kilnes 2012, pp. vf., 5ff.). Specifically, Götze shows that in post-conflict Bosnia-Herzegovina, the 
national Red Cross remained divided into two sub-organizations, the Red Cross of the Bosnian-Croatian Federation and the Red Cross of the Serbian Republic, both of which were aligned with powerful nationalist parties and groups, thereby reflecting the main fault lines of the BosnianHerzegovinian state (Götze 2004, esp. pp. 207-11). Similarly, civil society in the weak state of Pakistan has long reflected the competition between Islamist forces on the one hand and the military and other secular forces on the other (Zaidi 2006). Additional empirical findings and theoretical reflections are necessary, however, to explore these observations further.

Moreover, the existing literature suggests that power centre alignments may also influence the internal structures of individual civil society groups. Specifically, studies on civil society in China and Vietnam show that communist or socialist parties frequently set up sectoral mass organizations, such as worker, peasant or women groups, which operate within the sphere of civil society and may enhance their organizational autonomy over time (Perinova 2005, esp. p. 14; Wischermann et al. 2015). Sectoral organizations in this sense comprise, and are confined to, members of the same occupational status, gender or age (e.g. Hawes 1990). Both Migdal's work on (post-)revolutionary Mexico (1988, pp. 232ff.) and Linz's (2000, pp. 175ff.) research on mobilizational authoritarian regimes suggest that the pattern of sectoral organization can sometimes be found in civil society groups aligned with liberation parties and other types of revolutionary parties as well. Additional research is needed, however, to confirm and further investigate this assumption.

In addition, findings from Vietnam suggest that civil society organizations that are controlled by socialist or communist parties that rely on the Marxist-Leninist principle of democratic centralism will usually be highly hierarchical in nature and also practise democratic centralism themselves (Wischermann et al. 2015). This is because democratic centralism constitutes a direct link between socialist or communist parties and their affiliated mass organizations. Moreover, as an organizational mechanism, democratic centralism codifies the three core principles of subordinating the minority to the majority, the individual to the collective and the lower organizational units to the higher ones (Angle 2005; Wischermann et al. 2015). Similarly, drawing on Chakrabarty, Ruud (1996, p. 192) notes that in the segmented polity of India, where individuals and social groups often tend to be attached vertically to political and social elites, the internal structure of trade unions is also often hierarchical and leadercentred, an observation that may apply to other civil society organizations as well. Comparative research must further investigate, however, to what 
extent civil society groups aligned to power centres other than socialist or communist parties are also internally hierarchical, and why this might be the case.

Zaidi's (2006, p. 3557) work on Pakistan suggests that close linkages between civil society groups and alternative power centres lead to a "close accommodation between civil and uncivil society" or, in order words, to the emergence of dark sides in civil society. More specifically, Weijer and Kilnes $(2012$, p. 5$)$ note that in weak states "conflict tends to strengthen bonding social capital within identity groups, to the detriment of social capital across groups". Drawing on this, it might be concluded that civil society groups that are aligned with different types of alternative power centres in the weak state are likely to generate particularistic or bonding forms of social capital that run along, rather than cut across existing social cleavages. However, this issue has not been investigated in depth as of yet. Similarly, the question of how power centre alignments impact the ability of civil society groups to perform other democratic functions, such as watchdog and representative functions, or the function of being democratic intermediaries, has also remained largely unexplored to date.

The literature on weak states suggests that the strategies that state elites and alternative power centres employ to enhance their social and political control can often be reduced to patronage, violence or a combination of both (Eriksen 2005; Migdal 1988; ${ }^{4}$ Myrdal 1968; Schneckener 2006, p. 31 ). These strategies are bound to have an impact on national civil societies.

\subsection{Civil Society in the Context of Patronage AND CORRUPTION}

Both the empirically oriented literature on civil society and German transition theory show that in developing countries and countries undergoing political transformations, civil society groups are often tainted by patronage and corruption (e.g. Croissant 2000; Croissant et al. 2000; Holloway 1997; Lauth 2003). Similarly, the literature on weak states has found that patronage and corruption are particularly salient in weak states, which lack the capacity to implement administrative decisions and establish fullfledged social control over the entire population (e.g. Clapham 1982, p. 25; Eriksen 2005; Myrdal 1968; Migdal 1988; Schneckener 2006, p. 30). Against this backdrop, the present sub-chapter focuses on identifying the possible interfaces between civil society, patronage and corruption in the context of a weak state. 
Patronage and clientelism can be defined minimally as "a relationship of exchange between unequals" (Clapham 1982, p. 4), ${ }^{5}$ whereby the aspect of inequality can refer to either the socio-economic status or the political power of the parties involved. While the benefits traded can be both material and non-material in nature, clientelistic exchanges generally follow particularistic rather than universalistic criteria. Patron-client ties thus constitute interclass linkages, tying members of the lower social strata vertically to social and political elites. Nevertheless, clientelistic relations are, to a certain extent, mutually beneficial in character and entered into voluntarily (e.g. Roniger 1994a, p. 24; Günes-Ayata 1994; Landé 1977; Lemarchand 1981, p. 15; Piattoni 2001a, b; Scott and Kerkvliet 1977, pp. 439f.)

From the point of view of social and political elites, patronage is predominantly a strategy of social control (Migdal 1988; see also Clapham 1982, pp. 19f.; Günes-Ayata 1994, p. 21; Piattoni 2001a, p. 2; Roniger 2004), a pattern that often holds for corruption as well (Lorch 2014). The literature on weak states shows that where the state lacks the administrative capacity for authoritative decision-making, state leaders and bureaucratic elites frequently resort to patronage or corruption for the purpose of exercising a minimum of social and political control (e.g. Eriksen 2005, p. 400; Migdal 1988; Myrdal 1968; Schneckener 2006, p. 30). Patronage and corruption, in this sense, can take various forms, including political jobbery, that is, the appointment of state officials on the basis of loyalty rather than qualification, the biased allocation of development projects or the selective implementation of laws (Clapham 1982, pp. 25f.; Migdal 1988, pp. 217ff.; Smith 2004; WB 2016; Roniger 2004, pp. 357, 368). These observations are fully consistent with the older literature on patronage, which has pointed out that in contexts of administrative ineffectiveness, patron-client relations can be highly functional, because they can act as "addenda" "to institutions whose deficiencies they remedy" (Landé 1977, p. xxi). Thereby, patronage can serve functions as diverse as physical protection, the delivery of social services and representation (ibid; see also Clapham 1982; Lemarchand 1981, pp. 13ff.; Piattoni 2001a; Scott and Kerkvliet 1977). With regard to the latter function, Clapham (22ff.) has stressed, for instance, that in post-colonial states the introduction of the universal suffrage has often resulted in a blending of the security and welfare functions of clientelism with representative politics, leading to the emergence of a particular type of clientelism that he calls "clientelism of representation". Similarly, Landé has noted that, with regard to electoral 
politics, patronage sometimes "protects an ordinary member or citizen against the risk of being left out during the distribution of particularistic benefits, while giving elected officials some voters who can be counted upon" (Landé 1977: xxi-xxii). However, the use of patronage as a strategy of social control is not limited to state elites and political parties. Instead, very different types of alternative power centres, including large landowners, local strongmen, warlords or insurgent groups, can employ patronage in order to strengthen their social control over dependent populations and increase their political influence in weak states (Migdal 1988; see also Biró 2007).

Given that they prevent the emergence of class-based linkages and tie local constituencies vertically to social and political elites, patron-client relations usually form part of fragmented political orders (Landé 1977, p. xxixf.; Scott and Kerkvliet 1977, pp. 439f.). Moreover, as it centres on the distribution of particularistic benefits, patronage can reinforce social divisions and, thus, have a disruptive effect on social groups and communities. Patronage can thus further aggravate existing conflicts and reinforce dynamics of violence within oligarchic orders (e.g. Clapham 1982, pp. 1lf.; Landé 1977, p. xxxiif.; Piattoni 2001b, p. 199).

In most states where patronage is widespread, a relatively small number of patrons are confronted with a comparatively large number of (potential) clients. Consequently, such states are usually characterized by the existence of multiple clientelistic chains that link dependent constituencies, alternative power centres and state elites to each other. Within such clientelistic chains, alternative power centres and individual elites can act as middlemen, also referred to as clientelistic intermediaries, mediators or (electoral) brokers in the literature. Middlemen, in this sense, control access to the higher echelons of social and political power and, oftentimes, to avenues of resource conversion (Clapham 1982, pp. 8f., 13; GünesAyata 1994, pp. 22f.; Migdal 1988; Migdal and Schlichte 2005, p. 13; Myrdal 1968, pp. 814f.; Roniger 1994a, b).

How do these patterns and dynamics impact civil society? Scholarship on civil society based on normative democratic theory and international donor discourses usually consider patronage and civil society to be opposites. Similarly, they normally view civil society organizations as strong guardians against corruption (Holloway 1997; Roniger 1994a, pp. 8f.; for a prominent example see Mungiu-Pippidi 2013). Several studies on patronage and various critical studies on civil society, by contrast, have pointed to the complex interrelations between civil society and patronage 
in many contemporary settings (e.g. Alexander 1998, pp. 12ff.; GünesAyata 1994; Roniger 1994a, b; Piattoni 2001a, b).

In fact, the concepts of civil society and patronage share various important characteristics. Specifically, just like civil society organizations, patron-client networks generally exist between the public and the private realms. Moreover, both social interactions that take place in civil society and clientelistic exchanges are characterized by voluntarism, because, unlike primordial ties, patron-client relations are non-ascriptive in nature. Furthermore, despite their unequal character, clientelistic relationships are, to a certain extent, mutually beneficial in nature and may thus display various features that are supposedly found in civil society as well, such as reciprocity, solidarity or trust (Eisenstadt and Roniger 1984, pp. 9ff.; Günes-Ayata 1994, pp. 23ff.; Lemarchand 1981, p. 15; Piattoni 2001a, pp. 12f.; Powell 1977, p. 148; Roniger 1994a, pp. 4-13; Roniger,1998, p. 72, Scott and Kerkvliet 1977).

The literature on the demand side of clientelism suggests that in contexts where state elites and alternative power centres distribute patronage for the purpose of enhancing their social control, civil society groups might react by using clientelism as a deliberate strategy to realize their own goals as well (e.g. Günes-Ayata 1994; Piattoni 2001 a, b; Roniger 2004). Roniger (2004, p. 363) has argued, for instance, that researchers should treat clientelism as "one of various strategies stemming from civil society" and that it may sometimes constitute a "means to advance rights and popular demands" (ibid: 359). Similarly, Piattoni (2001b, p. 2) has noted that

clientelism and patronage are strategies for the acquisition, maintenance, and aggrandizement of political power, on the part of the patrons, and strategies for the protection and promotion of their interests, on the part of the clients, and ... their deployment is driven by given sets of incentives and disincentives. As such, their relative diffusion is connected with ... the emergence, transformation, and demise of constellations of institutional and historical circumstances which make these strategies politically more or less viable and socially more or less acceptable.

The same tendencies appear to apply to the strategic use of corruption by civil society actors as well (Lorch 2014). Patron-client relations and corruption connect civil society groups to state elites and alternative power centres, and it can be assumed that the stability of these linkages depends on the degree to which the respective civil society actors' expectations are met 
(for a similar argument see Günes-Ayata 1994, p. 23; Scott and Kerkvliet 1977, p. 448). The existing literature further suggests that civil society actors may enter into clientelistic alliances with state elites and alternative power centres in order to gain preferential access to resources and promote the material interests of their constituencies (e.g. Günes-Ayata 1994, pp. 25ff.; Piattoni 2001a, p. 7; Roniger 1994a, p. 10; Roniger 2004 , pp. 357ff.). Comparative empirical research is needed, however, to further explore these patterns in depth.

The literature on patronage also suggests that in weak states, civil society actors may act as middlemen in clientelistic chains involving state agencies and alternative power centres (Landé 1977; Piattoni 2001a, b; Powell 1977). As Piattoni (2001b, p. 203) argues, for instance, in posttraditional societies the position of the patron is accessible to anybody who has the necessary "capacity as mediator". Similarly, Landé (1977, p. xxxvi.) has noted that in contexts of administrative ineffectiveness, the role of the middleman can be assumed by a large variety of actors, including semi-educated peasant leaders and representatives of the middle class. By the same token, it has argued that many post-feudal societies have seen the emergence of "new brokers", such as "small intellectuals" (Powell 1977), ${ }^{6}$ whose mediating skills and "intermediate" socio-economic status enable them to perform this function (Powell 1977, pp. 149f.). As noted, third sector research and scholarship on civil society sometimes points to the intermediary function of civil society actors as well. However, they usually define this function in the democratic sense of the term, that is they often view civil society as an interlocutor, conveying the interests of marginalized social groups to the state (e.g. Croissant et al. 2000; Edwards and Hulme 1996a, b; Kramer 2000, p. 16; Lewis 2004). The possible overlaps and tensions between the democratic and the clientelist intermediary function of civil society in weak states have, by contrast, been insufficiently investigated to date.

Existing research on civil society and patronage further suggests that civil society groups embedded in patron-client networks are bound to reproduce the latter's organizational features (e.g. Clapham 1982, pp. 29f.; Roniger 1994b, p. 210). Most notably, civil society groups that engage in clientelistic exchanges are likely to replicate the "hierarchical logic of patronage" (Roniger 1998, p. 71), leading to the emergence or consolidation of strong intra-organizational hierarchies (ibid; see also Alexander 1998, pp. 13ff.; Günes-Ayata 1994, pp. 19ff.). Moreover, given that patronage is based on the distribution of particularistic 
benefits, it may lead to the emergence of standards for inclusion and exclusion, which run counter to universalism and fairness (Günes-Ayata 1994, pp. 24ff.; Piattoni 2001a, p. 18), compromising the democratic potential of civil society groups. Concurrently, Roniger (2004, p. 354) has noted that clientelism can constitute a form of "partial political mobilization". Consequently, it can be assumed that patron-client relations not only promote the emergence of fragmented political orders (e.g. Landé 1977, pp. xxixf.) but can also cause severe divisions within civil society. However, this assumption has not yet been discussed extensively in the literature on civil society.

Given that corruption has been found to exist inside the sphere of civil society as well (e.g. Holloway 1997; Trivunovic 2011), similar organizational problems can be expected when civil society groups in weak states engage in outright corruption. However, further comparative empirical evidence is needed to explore this assumption.

\subsection{Civil Society in the Context of Violence AND INSECURITY}

Several recent studies on civil society in weak states as well as some historical studies on civil society in the USA and Europe show that in contexts where the state's monopoly on force is not fully established, civil society groups are often tainted by violence (e.g. Englehardt 2011; Henry 2011; Knöbl 2006; Leonhard 2004; Mitra 2003; Reichardt 2004; Shah 2008). At the same time, the literature on weak states holds that state weakness is often associated with high levels of violence (e.g. Doornbos 2003; Milliken and Krause 2003; Schneckener 2006; Rotberg 2002, 2004). But how exactly does state weakness contribute to the emergence of violent practices within the sphere of civil society?

Where the bureaucratic institutions of the state are weak, the use of violence often constitutes a political strategy that can be employed by both state elites and alternative power centres for the purpose of exercising social control and enhancing their influence in the weak state (Biró 2007; Mair 2002; Migdal 1988; pp. 223ff.; Milliken and Krause 2003, pp. 4f.; Schneckener 2006, pp. 12f., 22, 31; Schneckener 2009). As Migdal (1988, pp. 223-28) argues, in weak states that lack capacity, state elites often resort to "dirty tricks", such as enforced disappearances, imprisonment or torture, in order to contain political opponents and safeguard 
their political survival. This strategy encompasses violent repressions against actors in civil society, such as student activists, trade union members or peasant leaders (for a similar argument see Rotberg 2004, pp. 16f.; Schneckener 2006, p. 31).

Moreover, the inability of the state to exercise a monopoly on force can lead to the emergence of alternative power centres that are capable of using violence as a political strategy as well. This includes violent non-state actors as diverse as armed big landowners and local strongmen, Communist insurgencies and liberation movements, terrorist groups or criminal gangs. The forms of violence employed by these different types of power centres differ greatly, owing to differences in their political motivations, strategies and organizational strength. Communist and liberation insurgencies, for instance, often employ violence for the purpose of capturing state power or achieving territorial control (Biró 2007; Doornbos 2003, pp. 47ff.; Mair 2002, pp. 9-20; Schneckener 2009). More specifically, Maoist insurgencies and other ideological insurgent movements in particular often build up their military capacity through step-by-step organizing and by gradually trying to win the hearts and minds of the local population (Biró 2007, pp. 30f.). Concurrently, they frequently target military installations or state institutions and seek to avoid civilian casualties (Mair 2002, pp. 9-20). Terrorist groups, by contrast, are often uninterested in territorial control and use violence indiscriminately, seeking to cause high numbers of civilian casualties. Still other violent power centres, such as warlords or local strongmen, may use violence as a means to realize their economic interests or carve out spaces of local autonomy for themselves (Biró 2007; Doornbos 2003, pp. 47ff.; Mair 2002, pp. 9-20; Schneckener 2009).

Weak states are often spaces of tremendous insecurity, either because the security agencies of the state fail to protect the population from onslaughts by violent non-state actors or because state elites and members of the state security apparatus engage in violent repression and, thus, constitute sources of insecurity themselves (e.g. Doornbos 2003; Milliken and Krause 2003, pp. 4f.; Schneckener 2006, p. 22; Rotberg 2004, p. 16). Furthermore, in contexts of violent conflict, rudimentary forms of security may, at times, not be provided by the state, but rather by non-state power centres with a capacity for violence, such as insurgent groups or armed local strongmen. More precisely, such non-state power centres may protect local communities from state repression or violent onslaughts by rival armed groups, thereby gaining local support (e.g. Andersen 2006; Migdal 1988; Ottaway 2004; Rotberg 2004, pp. 5ff.). 
What does all this mean for civil society? According to normative definitions, civil society is characterized by a high degree of "civility" that finds its expression in the use of dialogue and other means of peaceful dispute resolution and is, thus, diametrically opposed to violence (Gosewinkel 2003, p. 18; Henry 2011, pp. 97ff.; Leonhard 2004, p. 27; Knöbl 2006, p. 1; Reichardt 2004, p. 64; Stacey and Meyer 2005). This dichotomy between civil society and violence, which is dominant in the literature on civil society, is also reinforced by existing research on political violence (Henry 2011 , p. 97). But how can we explain the occurrence of violence within national civil societies in weak states, which several studies have observed?

As already mentioned earlier, some authors argue that violent practices characterize national civil societies particularly in those contexts where the state's monopoly on the use of force is weak (e.g. Englehardt 2011; Knöbl 2006; Reichardt 2004). More specifically, these studies have noted that where the centralization of violence in the hands of the state remains incomplete, it is often relatively easy for civil society and other social actors to access guns and other means of violence: a condition that increases the likelihood of social and political conflicts being settled through physical force. Moreover, the state's monopoly on force is generally seen to have a disciplinary impact on society, which, along with the provision of legal channels for expression, leads to social affect control and the development of social norms, which delegitimize the use of inter-personal violence (Knöbl 2006, esp. pp. 8ff.; Reichardt 2004, pp. 64-74). However, these studies do not clearly distinguish between civil society and society as a whole. In addition, their findings have so far remained largely unrelated to the different forms of violence that have been found to exist in weak states.

Stacey and Meyer $(2005$, p. 184) claim that civil society is capable of "deliberate violence", or, in other words, that civil society actors may employ violence as a deliberate strategy to realize their goals. To date, however, this argument has been insufficiently tested through comparative empirical research. Similarly, the questions of how the strategic use of violence by civil society actors may be related to the violent strategies that are employed by state elites and alternative power centres in weak states and what specific motives may drive civil society actors to resort to violence have, likewise, remained largely unexplored.

The few existing studies that focus explicitly on the relationship between civil society and violence suggest that civil society actors may employ violence both as a means self-defence (Henry 2011, pp. 102ff.; Reichardt 2004, p. 64) and as part of a broader strategy to realize certain higher 
political goals, such as democracy or the enlargement of civil society space (Reichardt 2004, pp. 64ff.). More specifically, it has been argued that civil society actors may resort to violence when they operate under an authoritarian regime in which peaceful forms of resistance have been proven ineffective (Henry 2011; Stacey and Meyer 2005, pp. 186ff.). This assumption is in line with Schneckener's (2006, pp. 28ff.) more general finding that, in contexts of state weakness, repression by state security forces can trigger social unrest and violent opposition. Moreover, it is also supported by the findings of Humphreys and Weinstein $(2006$, p. 9), who argue that people sometimes join armed rebellions in order to counter state repression in contexts where "non-violent channels" of political expression are blocked. However, whether civil society actors, driven by these or similar motives, are capable of using violence autonomously remains open to debate.

As indicated earlier, civil society groups in weak states are often affiliated with alternative power centres, and existing research shows that this also includes violent non-state actors, such as warlords, local strongmen or insurgent groups. Moreover, the existing literature also implies that civil society actors may enter into alliances with such violent power centres for purposes of protection as well as in order to gain access to economic resources or realize their goals (e.g. Biró 2007; Humphreys and Weinstein 2006; Migdal 1988; Ottaway 2004; Shah 2008; Verkoren and van Leeuwen 2014). More specifically, the case of the Burmese prodemocracy movement suggests that alliances with non-state armed groups can have a profound impact on civil society organizations. Specifically, they may come to support armed struggle or even transform themselves into armed groups over time (for a similar argument see Henry 2011). Further research is needed, however, to clarify the relationship between the existence of alliances between civil society groups and violent power centres on the one hand and the emergence of violent practices in civil society on the other.

Some historical and sociological studies argue that, under certain conditions, violence can, in fact, constitute an enabling condition for civil society to emerge (e.g. Gosewinkel 2003, p. 19; Leonhard 2004; Mitra 2003; Reichardt 2004, pp. 69f.). Drawing on the example of India, Mitra (2003, p. 1) notes that collective violence can sometimes constitute "a form of violent participation, which, in the final analysis, acts as the midwife of civil society". Similarly, other authors show that in the history of Europe, wars and violent conflicts have often played an important role in facilitating the emergence of a civil society space (e.g. Gosewinkel 
2003, p. 18f.; Leonhard 2004). Leonard (2004, pp. 29f.) shows, for instance, that both in Western Europe and in the USA the development of many voluntary associations was directly linked to nationalist mobilization in the context of warfare. These observations also suggest that some forms of violence tend to be more conducive to the emergence of civil society than others. However, existing studies have not yet related the emergence of civil society to the different forms of violence found in weak states.

A final important question relates to how an environment of violence and insecurity shapes the internal workings of civil society groups. Research, which touches upon this issue, tentatively suggests that the internal organizational structures of civil society groups that operate in contexts of insecurity tend to be rather hierarchical and centred on individual leaders (e.g. Krok-Paszkowska 2003, p. 120)7. To substantiate this assumption and gain a better understanding of how exactly insecurity may lead to the emergence of intra-organizational hierarchies within civil society groups, further comparative research is needed.

\subsection{The Intervening Variable: The Impact of Foreign Aid}

Research on civil society promotion by international donors is largely unanimous in stressing the enormous impact that foreign funding and other forms of donor support can have on civil society groups and their relationship to the state (e.g. Edwards and Hulme 1996a, b; Carothers and de Gramont 2013, esp. p. 176; Ottaway and Carothers 2000; Seckinelgin 2002). By the same token, the literature on weak states points to the important role of colonial state-building, external dependence and foreign funding in shaping the political structures and policy decisions of weak states (e.g. Chesterman et al. 2004; Clapham 2003; Eriksen 2005; Migdal 1988; Schneckener 2007). Against this backdrop, the present sub-chapter conceptualizes international donor influences as an important intervening variable that can have a tremendous impact on state-civil society relations in contexts of state weakness.

As discussed extensively elsewhere, colonial rulers around the world generally sought to extract from their colonies as many resources as possible at the lowest possible cost. Consequently, post-colonial state leaders frequently inherited state apparatuses with strong repressive, but very 
weak administrative, capacities (e.g. Leftwich 2004, pp. 145ff.). In addition, colonial powers generally relied on the co-optation of powerful social forces for the purpose of governing peripheral areas. As a result of this, formerly independent local patrons, such as feudal landowners or rural strongmen, were incorporated into the colonial state apparatus or turned into middlemen, connecting dependent segments of the population to the state. In many weak states, the prevalence of patronage is thus rooted in colonial state formation (Clapham 1982, p. 10; Kivimäki and Laakso 2000 , p. 20; Migdal 1988, e.g. pp. 262ff.).

The availability of external sources of funding, such as revenues from the export of natural resources or international aid, can also be conducive to weak state formation, because it may release political elites from the need of building strong state institutions for the purpose of taxation or the promotion of economic growth. Moreover, foreign aid in particular is often subject to political conditionalities, which curtail the recipient state's autonomy with regard to policy decision-making (e.g. Eriksen 2005 , pp. 398ff.; Smith 2004, pp. 151, 165ff.). In the 1970s and 1980s, donor conditionalities usually included administrative downsizing, market liberalization and privatization. Since the late 1980s, many donors began to promote the contracting-out of social services to NGOs and other civil society actors, thereby departing from their earlier approach of leaving the generation of welfare services entirely to the market (Banks et al. 2015; Edwards and Hulme 1996a, p. 2ff.; Seckinelgin 2002, Smith 2004 , pp. 166f.). Finally, starting from the mid-2000s, many international donor agencies adopted "bottom-up" or "demand-side" approaches to democracy promotion, which included civil society support as an important component (Carothers and de Gramont 2013, pp. 136ff.).

Against this backdrop, this sub-chapter focuses on the impact that foreign aid can have on the ability of civil society to perform functions normally ascribed to the state (see Sub-chap. 2.2), on the relationship between civil society actors and alternative power centres (see Sub-chap. 2.3) as well as on the way in which civil society is affected by the environment of patronage and corruption (see Sub-chap. 2.4) and of violence and insecurity (see Sub-chap. 2.5) that often prevails in weak states.

The existing literature shows that in many developing countries international donor support has strengthened the ability of local civil society groups to deliver social services not provided for by the state. Since the 1980s, international aid agencies have channelled increasing amounts of money through service-oriented NGOs. At the same time, they have often 
pressured weak state bureaucracies to outsource welfare tasks to civil society and to establish institutional agreements for contracting-out social services to NGOs, thereby promoting the emergence of mixed-welfare systems (e.g. Banks et al. 2015; Edwards and Hulme 1996a, pp. Iff.; INTRAC 2013; Smith 2004, pp. 166f.). Given that it usually offers rather attractive salaries and working conditions, the foreign-funded NGO sector has often lured educated professionals away from the civil service, leading to a brain drain that has weakened the administrative capacity of weak states even further (e.g. Abuzeid 2009). Moreover, in many weak states the growth of the local NGO sector has been donor-driven and has lacked sustainability, with many local NGOs disappearing when foreign funding dries up (Ottaway and Carothers 2000, pp. 299f.). However, the questions of how different kinds of national welfare systems shape the sizes and the structures of local NGO sectors and what role different international donor paradigms play in this regard have thus far remained largely unexplored.

Many international donors assume that by generating social capital, representing the interests of marginalized constituencies, acting as intermediaries linking disenfranchised communities to the state and by performing a watchdog function vis-à-vis the state, civil society groups in general, and donor funded NGOs in particular, can also contribute to democratic institution-building (Edwards and Hulme 1996a, b; Ottaway 2004, pp. 128f.; Carothers and Ottaway 2000; Ottaway and Carothers 2000; Seckinelgin 2002). In contrast, some more critical studies on NGOs have argued that there is often a trade-off between the latter's involvement in social service delivery and their ability to act as political advocates. Specifically, in order to receive foreign funding, local NGOs may expand their apolitical welfare activities at the expense of their advocacy programmes (e.g. Banks and Hulme 2012; Edwards and Hulme 1996a, pp. 5ff.). Moreover, the engagement of NGOs in large-scale and standardized service delivery is highly conducive to the professionalization and bureaucratization of these formerly more voluntary associations, a trend that is reinforced by the reporting and accounting requirements of international donors (Edwards and Hulme 1996a, p. 8; Ottaway and Carothers 2000; Uphoff 1996, pp. 23ff.). Accordingly, many local development NGOs in weak states are not member associations, but run by salaried staff, leading several authors to question their potential to generate social capital and serve a representative function for their constituencies (e.g. Carothers and Ottaway 2000; Ottaway 2004, p. 128; Ottaway and Carothers 2000). 
Furthermore, several critical works have argued that foreign aid may depoliticize local development NGOs and national civil societies in developing countries more generally (e.g. Banks et al. 2015, p. 709; Harriss 2002; Rahman 2006; Zaidi 2006, p. 3557). More specifically, it has been shown that donor funding often promotes the professionalization and bureaucratization of NGOs and that the latter often form part of international donor programmes, which conceptualize development as a technical and apolitical endeavour (e.g. Banks et al. 2015, p. 709). Harriss (2002) has argued that NGOs are thus part and parcel of what Ferguson has termed, the "anti-politics machine" of international aid. In addition, many international donors equate civil society with NGOs and, therefore, allocate huge amounts of resources to support the growth of the NGO sector, while marginalizing other, more politically active civil society actors, such as social movements (e.g. Edwards 2004, pp. 14, 24; Ottaway and Carothers 2000, pp. 295f.; Seckinelgin 2002). However, the question of how exactly foreign funding depoliticizes civil society in weak states and what role different donor paradigms, the structure of the local NGO sector and the influence of alternative power centres play in this regard have not, as yet, been fully explored.

The literatures on civil society, state weakness and foreign aid all suggest that international donor support can act as an intervening variable that can have a strong impact on the relationship between civil society, the state and alternative power centres (e.g. Carothers and de Gramont 2013; Carothers and Ottaway 2000; Ottaway and Carothers 2000; Shah 2008; Seckinelgin 2002; Zaidi 2006). For example, international donors often make their financial support to weak states conditional on consultation with civil society, thereby strengthening the latter's position vis-àvis the state (e.g. Seckinelgin 2002, pp. 18ff.). Moreover, by providing them with an independent resource base, foreign aid can also enhance the autonomy of civil society groups from the state and alternative power centres. However, this increase in local autonomy often comes at the cost of increased dependence on foreign donors, making civil society groups susceptible to foreign agenda-setting (Shah 2008, p. 43).

At the same time, foreign aid may also be appropriated by alternative power centres that oppose the state, including both non-violent opposition parties and violent non-state actors, such as warlords or insurgent groups. As noted earlier, such alternative power centres may try to exert social control over local constituencies by delivering welfare services through co-opted civil society groups or may even establish loyal civil society 
groups in order to access donor funding (Biró 2007, pp. 42f.; Ottaway 2004; Schneckener 2009, p. 11). During the Cold War, many "Western" aid agencies promoted explicitly apolitical NGOs in order to marginalize Communist parties and other leftist movements (e.g. Carothers and Ottaway 2000, pp. 6ff.; Ottaway and Carothers 2000, p. 299), which, in turn, were often supported by the Soviet Union (Mair 2002, pp. 13ff.). However, additional research is needed to determine when international donor support enhances the autonomy of civil society, breaking the ties between civil society groups and alternative power centres; and when such support instead serves to strengthen existing linkages between civil society groups and alternative power centres or state elites.

Regarding the impact that international donor support can have on the relationship between civil society, patronage and corruption, critical scholarship has argued that foreign funding can spur corruption in the NGO sector (e.g. Holloway 1997, Ottaway 2004, p. 132). Weak states usually lack the capacity to monitor foreign-funded NGOs (e.g. Edwards and Hulme 1996a, p. 8f.): a condition that can enable the emergence of clientelistic practices within these groups. Moreover, in weak states the contracting-out of welfare services, which is often promoted by foreign donors, frequently leads to the emergence of complex patterns of patronage and corruption (e.g. Smith 2004, p. 166). This tendency is bound to affect civil society groups acting as social service contractors as well. Nevertheless, the question of how donor interventions influence the way in which local civil society actors relate to the manifold patronage and corruption networks that exist in weak states has remained largely unexplored.

Existing research shows that patronage and corruption are facilitated by a lack of accountability and that clientelistic exchanges usually follow a hierarchical logic. Critical scholarship on foreign-funded NGOs finds that the internal organizational structures of these civil society groups are often hierarchical and lack transparency (e.g. Ottaway and Carothers 2000, pp. 305f.; Uphoff 1996). More specifically, Tandon (1996, p. 56) claims that many NGOs in developing countries are characterized by informality and exclusiveness and are dominated by "founder-leaders". A quantitative study of 492 NGOs in six Asian countries finds that internal hierarchies in NGOs are strongly correlated with high levels of foreign funding (Lyons and Nivison-Smith 2008). Several qualitative works also suggest that interactions with foreign donors can render the internal structures of local NGOs more hierarchical, because those NGO leaders who are able to "talk the donor's talk" often acquire disproportionate influence over their 
organizations (Ottaway and Carothers 2000, pp. 300ff.; Shah 2008; Zaidi 2006 , p. 3557). Moreover, donor reporting requirements frequently lead to the distortion of NGO accountability upward to their donors, at the expense of downward accountability towards their beneficiaries (Edwards and Hulme 1996b, p. 254; see also Tandon 1996). To date, however, the relationship between donor influence, internal organizational hierarchies and the involvement of civil society groups in patronage and corruption has been insufficiently explored.

The literature on civil society, state weakness and foreign aid, which was reviewed for the purposes of this study, is largely silent on how international donor support influences the way in which civil society actors relate to the patterns of violence that can exist in weak states. Some authors have noted very generally that foreign donors may protect local civil society actors from state repression and threats by political elites (e.g. Carothers and Ottaway 2000, pp. 14f.; Shah 2008, p. 43). However, scholars have also found that foreign-funded civil society groups are sometimes affiliated with violent power centres, such as insurgents or warlords, that establish civil society organizations in order to be able to engage with the international community (e.g. Biró 2007). Additional research is thus needed to further explore the relationship between civil society, violence and donor support in weak states.

In summary, a review of the literatures on civil society, governance in areas of limited statehood, state weakness, patronage and corruption, violent non-state actors and on international development cooperation thus suggests an analytical framework consisting of five major categories of influences on national civil societies in weak states. With regard to the national level, these categories are the existence of an environment in which non-state actors perform functions usually ascribed to the state (Sub-chap. 2.2), the lack of state autonomy and the existence of competition for social control between different alternative power centres (Sub-chap. 2.3), a context of patronage and corruption (Sub-chap. 2.4) and an environment of violence and insecurity (Sub-chap. 2.5). International donor influences constitute an important intervening variable that can have a significant impact on the relationship between civil society and state weakness across the four other categories (Sub-chap. 2.6). The following chapters apply this analytical framework to Bangladesh and the Philippines. 


\section{Notes}

1. For an overview of the democratic functions attributed to NGOs in particular see for example, Edwards and Hulme (1996a, b) and Seckinelgin (2002).

2. This corresponds with the observation of other authors that the assumption of the existence of a strong state is implicit in many conventional, normative civil society theories, which makes it difficult to apply these theories to contexts of state weakness (Croissant et al. 2000, p. 17; Knöbl 2006, p. 13; Shah 2008).

3. My definition of the term "alternative power centre" is based on Migdal (1988). It should be noted, however, that Migdal uses the term "power centre", rather than "alternative power centre" and that his definition does not explicitly refer to "power centres" as "collectives of political and/or social elites".

4. Migdal uses the term "dirty tricks" to describe acts of political violence by state elites.

5. For a similar definition see for example, Landé (1977, p. xx) and Roniger (2004, p. 353). Like many other works (e.g. Piattoni 2001 a, p. 4; Roniger 2004 , p. 354), the present study uses the terms patronage and clientelism interchangeably.

6. As cited in Powell (1977, p. 150).

7. On the relationship between the existence of a restrictive environment and the development of internal hierarchies in different types of organizations, see also Rueschemeyer (1998, p. 13f; 16).

\section{REFERENCES}

Abuzeid, F. 2009. Foreign Aid and the "Big Push" Theory: Lessons from SubSaharan Africa. Stanford Journal of International Relations XI(1): 16-23.

Alexander, J.C. 1998. Introduction: Civil Society I, II, III: Constructing an Empirical Concept form Normative Controversies and Historical Transformations. In Real Civil Societies: Dilemmas of Institutionalization, ed. J.C. Alexander, 1-20. London: Sage Publications Ltd.

Andersen, L. 2006. Security Sector Reform in Fragile States. DIIS Working Paper, 2006/15. Copenhagen: DIIS, Danish Institute of International Studies.

Angle, S.C. 2005. Decent Democratic Centralism. Political Theory 33(4): 518-546.

Anheier, H.K., E. Priller, and A. Zimmer. 2000. Zur zivilgesellschaftlichen Dimension des Dritten Sektors. In Die Zukunft der Demokratie: Herausforderungen im Zeitalter der Globalisierung, ed. H.-D. Klingemann and F. Neidhardt, 71-98. Berlin: Edition sigma. 
Anheier, H.K., K. Helmut, and M. Freise. 2003. Der Dritte Sektor im Wandel: zwischen New Public Management und Zivilgesellschaft. In Zivilgesellschaftnational und transnational, WZB-Jahrbuch 2003, ed. D. Gosewinkel, D. Rucht, W. van den Daele, and J. Kocka, 129-150. Berlin: Edition sigma.

Banks, N., and D. Hulme. 2012. The Role of NGOs and Civil Society in Development and Poverty Reduction. Brooks World Poverty Institute Working Paper No. 171, http://papers.ssrn.com/sol3/papers.cfm?abstract_ id=2072157, date accessed 28 April 2016.

Banks, N., D. Hulme, and M. Edwards. 2015. NGOs, States, and Donors Revisited: Still Too Close for Comfort? World Development 66: 707-718.

Beisheim, M., A. Liese, and J. Lorch. 2014. Introduction: Transnational Partnerships for Sustainable Development. In Transnational Partnerships: Effectively Providing for Sustainable Development? ed. M. Beisheim and A. Liese, 3-16. Houndmills Basingstoke: Palgrave Macmillan.

Biró, D. 2007. The (Un)bearable Lightness... of Violence. In State Failure Revisited II: Actors of Violence and Alternative Forms of Governance Report 89/2007, ed. T. Debiel and D. Lambach, 7-49. Duisburg-Essen: INEF, Institut für Entwicklung und Frieden.

Carothers, T., and D. de Gramont. 2013. Development Aid Confronts Politics: The Almost Revolution. Washington, DC: Carnegie Endowment for International Peace.

Carothers, T., and M. Ottaway. 2000. The Burgeoning World of Civil Society. In Funding Virtue: Civil Society Aid and Democracy Promotion, ed. M. Ottaway and T. Carothers, 3-20. Washington, DC: Carnegie Endowment for International Peace.

CCS-LSE (Centre for Civil Society of the London School of Economics and Political Science). 2006. Report on Activities. July 2005-August 2006, http:// eprints.Ise.ac.uk/29398/1/CCSReport05_06.pdf, date accessed 12 April 2016.

Chesterman, S., M. Ignatieff, and R. Thakur. 2004. Making States Work: State Failure and the Crisis of Governance. New York: United Nations University Press.

Clapham, C. 1982. Clientelism and the State. In Private Patronage and Public Power: Political Clientelism in the Modern State, ed. C. Clapham, 1-36. London: Pinter.

Clapham, C. 2003. The Challenge to the State in a Globalized World. In State Failure, Collapse, and Reconstruction, ed. J. Milliken, 25-44. Malden, MA/ Oxford: Blackwell Publishing.

Cohen, J.L., and A. Arato. 1992. Civil Society and Political Theory. Cambridge, MA/London: MIT Press. 
Croissant, A. 2000. Zivilgesellschaft und Transformation in Ostasien. In Systemwechsel 5. Zivilgesellschaft und Transformation, ed. W. Merkel, 335-372. Opladen: Leske+Budrich.

Croissant, A., H.-J. Lauth, and W. Merkel. 2000. Zivilgesellschaft und Transformation: Ein internationaler Vergleich. In Systemwechsel 5. Zivilgesellschaft und Transformation, ed. W. Merkel, 9-49. Opladen: Leske+Budrich.

Doornbos, M. 2003. State Collapse and Fresh Starts: Some Critical Reflections. In State Failure, Collapse, and Reconstruction, ed. Jennifer Milliken, 45-62. Malden, MA/Oxford: Blackwell Publishing.

Edwards, M. 2004. Civil Society. Cambridge: Polity Press.

Edwards, M., and D. Hulme (eds.). 1996a. Beyond the Magic Bullet: NGO Performance and Accountability in the Post-Cold War World, 1-20. Sterling: Kumarian Press.

Edwards, M., and D. Hulme. 1996b. Beyond the Magic Bullet? Lessons and Conclusions. In Beyond the Magic Bullet: NGO Performance and Accountability in the Post-Cold War World, ed. M. Edwards and D. Hulme, 254-266. Sterling: Kumarian Press.

Eisenstadt, S.N., and L. Roniger. 1984. Patrons, Clients and Friends: Interpersonal Relations and the Structure of Trust in Society. Cambridge: Cambridge University Press.

Englehardt, N. 2011. What Makes Civil Society Civil? The State and Social Groups. Polity 43: 337-557.

Eriksen, S. 2005. The Politics of State Formation: Contradictions and Conditions of Possibility. European Journal of Development Research 17(3): 396-410.

Evans, P.B., D. Rueschemeyer, and T. Skocpol (eds.). 1985. Bringing the State Back In. Cambridge: Cambridge University Press.

Evers, A., and J. Laville. 2004. Introduction. In The Third Sector in Europe, ed. A. Evers and J. Laville, 1-9. Cheltenham: Edward Elgar Publishing.

Götze, C. 2004. Die Bedeutung von Staatsversagen und Anomie für zivilgesellschaftliche Organisationen: Beispiele aus Bosnien-Herzegowina und Albanien. In Zivilgesellschaft —national und transnational, ed. D. Gosewinkel, D. Rucht, W. van den Daele, and J. Kocka, 201-222. Berlin: Edition sigma.

Gosewinkel, D. 2003. Zivilgesellschaft-Eine Erschließung des Themas von seinen Grenzen her. Discussion Paper No. SP IV 2003-505. Berlin: WZB, Wissenschaftszentrum Berlin für Sozialforschung.

Gosewinkel, D. and S. Reichardt (2004). Ambivalenzen der Zivilgesellschaft. Gegenbegriffe, Gewalt und Macht, Discussion Paper No. SP IV 2004-501. Berlin: Wissenschaftszentrum Berlin für Sozialforschung (WZB).

Gosewinkel, D. and D. Rucht. 2004. "History meets sociology": Zivilgesellschaft als Prozess. In Zivilgesellschaft-national und transnational, ed. D. Gosewinkel, D. Rucht, W. van den Daele, and J. Kocka, 11-28. Berlin: Edition sigma. 
Gosewinkel, D., D. Rucht, W. van den Daele, and J. Kocka. 2004. Einleitung: Zivilgesellschaft-national und transnational. In Zivilgesellschaft-national und transnational, ed. D. Gosewinkel, D. Rucht, W. van den Daele, and J. Kocka, 11-28. Berlin: Edition sigma.

Guan, L.H. 2004. Introduction: Civil Society in Southeast Asia. In Civil Society in Southeast Asia, ed. L.H. Guan, 1-26. Singapore: NIAS Press.

Günes-Ayata, A. 1994. Clientelism: Premodern, Modern, Postmodern. In Democracy, Clientelism and Civil Society, ed. L. Roniger and A. Günes-Ayata, 19-28. Boulder, CO: Lynne Rienner Publishers.

Harriss, J. 2002. Depoliticizing Development: The World Bank and Social Capital. London: Anthem Press.

Hawes, G. 1990. Theories of Peasant Revolution: A Critique and Contribution from the Philippines. World Politics 42(2): 261-298.

Heng, R.H.-K. 2004. Civil Society Effectiveness and the Vietnamese State: Despite or Because of the Lack of Autonomy. In Civil Society in Southeast Asia, ed. L.H. Guan, 144-166. Singapore: NIAS Press.

Henry, N. 2011. Civil Society amid Civil War: Political Violence and Non-violence in the Burmese Democracy Movement. Global Society 25(1): 97-111.

Holloway, R. 1997. NGOs: Loosing the Moral High Ground-Corruption and Misrepresentation. Lima: 8th International Anti-Corruption Conference (IAAC).

Howell, J. 1999. Manufacturing Civil Society from the Outside: Some Dilemmas and Challenges. Paper presented at the European Association of Development Research and Training Institutes (EADI) Conference, September 1999.

Humphreys, M. and J.M. Weinstein. 2006. Who Rebels? The Determinants of Participation in Civil War. UCLA Comparative Politics Workshop 27 January 2006, http://www.sscnet.ucla.edu/polisci/cpworkshop/papers/weinstein. pdf, date accessed 12 April 2016.

INTRAC (International NGO Training and Research Centre). 2013. Evaluation Insights: Support to Civil Society-Emerging Evaluation Lessons (INTRAC United Kingdom).

Kaviraj, S. 2001. In Search of Civil Society. In Civil Society: History and Possibilities, ed. S. Kaviraj and S. Khilnani, 287-323. Cambridge: Cambridge University Press.

Kivimäki, T., and L. Laakso. 2000. Overview of African Conflicts. In Greed, Grievance and Weak States: Overview of African Conflicts, ed. Timo Kivimäki and Liisa Laakso, 11-23. Helsinki: University of Helsinki.

Knöbl, W. 2006. Zivilgesellschaft und staatliches Gewaltmonopol: zur Verschränkung von Gewalt und Zivilität. Mittelweg 36 15(1): 61-84.

Kramer, R.M. 2000. A Third Sector in the Third Millenium? Voluntas: International Journal of Voluntary and Nonprofit Organizations 11(1): 1-23. 
Krok-Paszkowska, A. 2003. Samoobrona: The Polish Self-Defence Movement. In Uncivil Society? Contentious Politics in Post-Communist Europe, ed. P. Kopecky and C. Mudde, 114-133. London: Routledge.

Lamping, W., H. Schridde, S. Plaß, and B. Blanke. 2002. Der Aktivierende Staat. Positionen, Begriffe, Strategien. Bonn: Friedrich-Ebert-Stiftung.

Landé, C.H. 1977. The Dyadic Basis of Clientelism. In Friends, Followers, and Factions: A Reader in Political Clientelism, ed. S. Schmidt, L. Guasti, C.H. Landé, and J.C. Scott, xiii-xxxvii. Berkeley, CA: University of California Press.

Lauth, H.-J. 2003. Zivilgesellschaft als Konzept und die Suche nach ihren Akteuren. In Die Praxis der Zivilgesellschaft. Akteure, Handeln und Strukturen im internationalen Vergleich, ed. A. Bauerkämper, 31-56. Frankfurt/Main: Campus.

Leftwich, A. 2004. Theorizing the State. In Politics in the Developing World, ed. Peter J. Burnell and Vicky Randall, 140-155. Oxford: Oxford University Press.

Lemarchand, R. 1981. Comparative Political Clientelism: Structure, Process and Optic. In Political Clientelism, Patronage and Development, ed. S.N. Eisenstadt and R. Lemarchand, 7-34. Beverly Hills, CA/London: Sage.

Leonhard, J. 2004. Zivilität und Gewalt: Zivilgesellschaft, Bellizismus und Nation. In Ambivalenzen der Zivilgesellschaft. Gegenbegriffe, Gewalt und Macht. Discussion Paper No. SP IV 2004-501, ed. D. Gosewinkel and S. Reichardt, 26-41. Berlin: WZB, Wissenschaftszentrum Berlin für Sozialforschung.

Lewis, D. 2001. Civil Society in Non-Western Contexts: Reflections on the 'Usefulness' of a Concept. Civil Society Working Paper Series 13. London: London School of Economics and Political Science.

Lewis, J. 2004. The State and the Third Sector in Modern Welfare States: Independence, Instrumentality, Partnership. In The Third Sector in Europe (Globalization \& Welfare), ed. A. Evers and J. Laville, 169-187. Cheltenham/ Northampton, MA: Edward Elgar.

Linz, J.J. 2000. Totalitarian and Authoritarian Regimes. Boulder, CO: Lynne Rienner Publishers.

Lorch, J. 2006. Civil Society under Authoritarian Rule: The Case of Myanmar. Südostasien aktuell 25(6): 3-37.

Lorch, J. 2008. The (Re)-Emergence of Civil Society in Areas of State Weakness: The Case of Education in Myanmar. In Dictatorship, Disorder and Decline in Myanmar, ed. M. Skidmore and T. Wilson, 151-176. Canberra: ANU E-Press.

Lorch, J. 2014. Civil Society and Corruption in Weak States: Opposites or Bedfellows? A Comparison of Bangladesh and the Philippines. Paper presented at the ECPR General Conference in Glasgow, 3-6 September 2014.

Lyons, M., and I. Nivison-Smith. 2008. Does Foreign Funding of Civil Society Encourage Democratic or Good Corporate Governance? The Case of Asia. Paper presented at the ISTR Conference, 09.-12 July 2008 (Barcelona). 
Mair, S. 2002. Die Globalisierung privater Gewalt. Kriegsherren, Rebellen, Terroristen und organisierte Kriminalität, SWP-Studie S, 10 April 2010. Berlin: Stiftung Wissenschaft und Politik (SWP).

Migdal, J.S. 1988. Strong Societies and Weak States: State-Society Relations and State Capabilities in the Third World. Princeton, NJ: Princeton University Press.

Migdal, J.S., and K. Schlichte. 2005. Rethinking the State. In The Dynamics of States: The Formation and Crises of State Domination, ed. K. Schlichte, 1-40. Aldershot/Burlington: Ashgate Publishing.

Milliken, J., and K. Krause. 2003. State Failure, State Collapse and State Reconstruction: Concepts, Lessons and Strategies. In State Failure, Collapse \& Reconstruction, ed. J. Milliken, 1-24. Malden, MA/Oxford: Blackwell Publishing.

Mitra, S.K. 2003. Collective Violence and the Making of Civil Society: India in European Perspective. Paper presented at the International Seminar on Political and Social Transition in India and Europe. Leipzig: Leipzig University.

Monga, C. 2009. Uncivil Societies: A Theory of Socio-Political Change. Policy Research Working Paper 4942. World Bank.

Mungiu-Pippidi, A. 2013. Controlling Corruption through Collective Action. Journal of Democracy 24(1): 101-115.

Myrdal, G. 1968. Asian Drama: An Inquiry into the Poverty of Nations. New York, NY: Pantheon.

Ottaway, M. 2004. Civil Society. In Politics in the Developing World, ed. P.J. Burnell and V. Randall, 120-135. Oxford: Oxford University Press.

Ottaway, M., and T. Carothers. 2000. Towards Civil Society Realism. In Funding Virtue: Civil Society Aid and Democracy Promotion, ed. M. Ottaway and T. Carothers, 292-310. Washington, DC: Carnegie Endowment for International Peace.

Perinova, M. 2005. Civil Society in Authoritarian Regime: The Analysis of China, Burma and Vietnam. Lund: Lund University.

Piattoni, S. 2001a. Clientelism in Historical and Comparative Perspective. In Clientelism, Interests, and Democratic Representation: The European Experience in Historical and Comparative Perspective, ed. S. Piattoni, 1-30. Cambridge: Cambridge University Press.

Piattoni, S. 2001b. Clientelism in Historical and Comparative Perspective. In Clientelism, Interests, and Democratic Representation: The European Experience in Historical and Comparative Perspective, ed. S. Piattoni, 193-212. Cambridge: Cambridge University Press.

Powell, J.D. 1977. Peasant Society and Clientelist Politics. In Friends, Followers, and Factions: A Reader in Political Clientelism, ed. S. Schmidt, L. Guasti, C.H. Landé, and J.C. Scott, 147-161. Berkeley, CA: University of California Press. 
Priller, E., and A. Zimmer. 2003. Dritte-Sektor-Organisationen zwischen "Markt" und "Mission". In Zivilgesellschaft-nationalund transnational, WZB-Jahrbuch 2003, ed. D. Gosewinkel, D. Rucht, W. van den Daele, and J. Kocka, 105-128. Berlin: Edition sigma.

Putnam, R.D., with R. Leonardi, and R.Y. Nanetti. 1993. Making Democracy Work: Civic Traditions in Modern Italy. Princeton, NJ: Princeton University Press.

Rahman, S. 2006. Development, Democracy and the NGO Sector: Theory and Evidence from Bangladesh. Journal of Development Societies 22(4): 451-473.

Reichardt, S. 2004. Gewalt und Zivilität im Wandel: Konzeptionelle Überlegungen zur Zivilgesellschaft aus historischer Sicht. In Zivilgesellschaft-national und transnational, ed. D. Gosewinkel, D. Rucht, W. van den Daele, and J. Kocka, 61-81. Berlin: Edition sigma.

Risse, T. 2012. Governance Configurations in Areas of Limited Statehood: Actors, modes, institutions, and resources. SFB-Governance Working Paper Series 32. Berlin: Sonderforschungsbereich (SFB) 700.

Risse, T. 2015. Governance in Areas of Limited Statehood. In The Oxford Handbook of Governance, ed. D. Levi-Faur, (2012), 699-715. Oxford: OUP.

Rombouts, H. 2006. Civil Society Participation in Fragile States: Critical Thoughts on the New Development Paradigm and its Implementation. Discussion Paper 2006.06. Antwerpen: University of Antwerpen.

Roniger, L. 1994a. The Comparative Study of Clientelism and the Changing Nature of Civil Society in the Contemporary World. In Democracy, Clientelism and Civil Society, ed. L. Roniger and A. Günes-Ayata, 1-19. Boulder, CO: Lynne Rienner Publishers.

Roniger, Luis. 1994b. Conclusions: The Transformation of Clientelism and Civil Society. In Democracy, Clientelism and Civil Society, ed. Luis Roniger and Ayse Günes-Ayata, 207-214. Boulder, CO: Lynne Rienner Publishers.

Roniger, L. 1998. Civil Society, Patronage, and Democracy. In Real Civil Societies. Dilemmas of Institutionalization, ed. J.C. Alexander, 66-83. London: Sage Publications Ltd.

Roniger, L. 2004. Political Clientelism, Democracy, and Market Economy. Comparative Politics 36(3): 353-375.

Rotberg, R.I. 2002. The New Nature of Nation State Failure. The Washington Quarterly 25(3): 85-96.

Rotberg, R.I. 2004. Failed States, Collapsed States, Weak States: Causes and Indicators. In When States Fail: Causes and Consequences, ed. R.I. Rotberg, 1-25. Princeton, NJ: Princeton University Press.

Rueschemeyer, D. 1998. The Self-Organization of Society and Democratic Rule: Specifying the Relationship. In Participation and Democracy East and West: Comparisons and Interpretations, ed. D. Rueschemeyer, M. Rueschemeyer, and B. Wittrock, 9-25. Armonk, NY/London: M.E. Sharpe. 
Rueschemeyer, D., M. Rueschemeyer, B. Wittrock (1998a). Introduction. In Participation and Democracy East and West. Comparisons and Interpretations. ed. D. Rueschemeyer, M. Rueschemeyer, and B. Wittrock, pp. 3-8. NY/ London: M.E. Sharpe, Armonk.

Rueschemeyer, D., M. Rueschemeyer, B. Wittrock (1998b). Conclusion. Contrasting Patterns of Participation and Democracy. In Participation and Democracy East and West. Comparisons and Interpretations. ed. D. Rueschemeyer, M. Rueschemeyer, and B. Wittrock, pp. 265-284. NY/London: M.E. Sharpe, Armonk.

Rueschemeyer, D. 2009. Usable Theory: Analytic Tools for Social and Political Research. Princeton, NJ: Princeton University Press.

Ruud, A.E. 1996. State, Society and Bureaucracy in Rural India-and the Problem of Their Interaction. In Weak? Strong? Embedded? New Perspectives on StateSociety Relations in the Non-Western World, ed. M. Halskov Hansen and A. Engelsen Ruud. Oslo: University of Oslo.

Schneckener, U. 2006. States at Risk: Zur Analyse fragiler Staatlichkeit. In Fragile Staatlichkeit. "States at Risk" zwischen Stabilität und Scheitern, Internationale Politik und Sicherheit, ed. U. Schneckener, Band 59. 9-40. Baden-Baden: Nomos.

Schneckener, U. 2007. Internationales Statebuilding: Dilemmata, Strategien und Anforderungen an die deutsche Politik. SWP-Studien, 2007/S 10, May 2007. Berlin: Stiftung Wissenschaft und Politik (SWP).

Schneckener, U. 2009. Spoilers or Governance Actors? Engaging Armed NonState Groups in Areas of Limited Statehood. SFB-Governance Working Paper Series 21. Berlin: Collaborative Research Center (SFB).

Scott, J.C., and B.J. Kerkvliet. 1977. How Traditional Rural Patrons Lose Legitimacy: A Theory with Special Reference to Southeast Asia. In Friends, Followers, and Factions: A Reader in Political Clientelism, ed. S. Schmidt, L. Guasti, C.H. Landé, and J.C. Scott, 439-458. Berkeley, CA: University of California Press.

Seckinelgin, H. 2002. Civil Society as a Metaphor for Western Liberalism. Civil Society Working Paper 21. London: London School of Economics.

Shah, S. 2008. Civil Society in Uncivil Places: Soft State and Regime Change in Nepal. Policy Studies 48. Washington, D.C.: East-west Center.

Smith, B. 2004. State-Building. In Politics in the Developing World, ed. P.J. Burnell and V. Randall, 155-170. Oxford: Oxford University Press.

South, A. 2007. Ceasefires and Civil Society: The Case of the Mon. In Ethnic Diversity in Burma, ed. M. Gravers, 149-177. Copenhagen: NIAS Press.

Stacey, S., and M. Meyer. 2005. Civil Society and Violence: A Research Agenda. Journal of Civil Society 1(2): 181-190.

Stepan, A. 1985. State Power in the Southern Cone of Latin America. In Bringing the State Back In, ed. P.B. Evans, D. Rueschemeyer, and T. Skocpol, 317-343. Cambridge: Cambridge University Press. 
Tandon, R. 1996. Board Games: Governance and Accountability in NGOs. In Beyond the Magic Bullet: NGO Performance and Accountability in the Post-Cold War World, ed. M. Edwards and D. Hulme, 53-62. Sterling: Kumarian Press.

Trivunovic, M. 2011. Countering NGO Corruption: Rethinking the Conventional Approaches. CMI U4 2011/3. Bergen: Chr. Michelsen Institute.

von Trotha, T. 2005. Der Aufstieg des Lokalen. Aus Politik und Zeitgeschichte (APuZ), 28-29/2005, 32-38.

Uphoff, N. 1996. Why NGOs Are Not a Third Sector: A Sectoral Analysis with Some Thoughts on Accountability, Sustainability, and Evaluation. In Beyond the Magic Bullet. NGO Performance and Accountability in the Post-Cold War World, ed. M. Edwards and D. Hulme, 23-39. Sterling, VA: Kumarian Press.

Verkoren, W., and M. van Leeuwen. 2014. Civil Society in Fragile Contexts. In The Handbook of Global Security Policy, ed. M. Kaldor and I. Rangelov, 463-481, Blackwell Publishing.

de Weijer, F., and U. Kilnes. 2012. Strengthening Civil Society? Reflections on International Engagement in Fragile States. Discussion Paper No. 135. European Centre for Development and Policy Management (ecdpm).

Weiss, L., and L.M. Hobson. 1995. States and Economic Development: A Comparative Historical Analysis. Cambridge: Wiley.

Wischermann, J. 2005. Towards Good Society? Civil Society Actors, the State, and the Business Class in Southeast Asia: Facilitators of or Impediments to a Strong, Democratic, and Fair Society? In Towards Good Society. Civil Society Actors, the State, and the Business Class in Southeast Asia. Berlin: Heinrich Böll Stiftung.

Wischermann, J. et al. 2015. Under the State's Thumb: Results from an Empirical Survey of Civic Organizations in Vietnam. GIGA Working Paper No. 276. Hamburg: GIGA.

WB (World Bank). 2016. Helping Countries to Combat Corruption: The Role of the World Bank. 2. Corruption and Economic Development, http://wwwl.worldbank.org/publicsector/anticorrupt/corruptn/cor02.htm, date accessed 30 April 2016.

Yang, D.D.-H. 2004. Civil Society as an Analytic Lens for Contemporary China. China: An International Journal 2(1): 1-27.

Zaidi, S.A. 2006. Pakistan: Civil and Uncivil Society. Economic and Political Weekly, 19 August 2006, 3556-3557. 
Open Access This chapter is licensed under the terms of the Creative Commons Attribution 4.0 International License (http://creativecommons.org/licenses/ by $/ 4.0 /$ ), which permits use, sharing, adaptation, distribution and reproduction in any medium or format, as long as you give appropriate credit to the original author(s) and the source, provide a link to the Creative Commons license and indicate if changes were made.

The images or other third party material in this chapter are included in the chapter's Creative Commons license, unless indicated otherwise in a credit line to the material. If material is not included in the chapter's Creative Commons license and your intended use is not permitted by statutory regulation or exceeds the permitted use, you will need to obtain permission directly from the copyright holder. 